\title{
Empirical Analysis of Mcdonald's Fast-Food in Malaysia Based on Halāl Food Regulations in Sūrah Al-Mā'idah
}

\author{
Bey Zekkoub Abdelali ${ }^{1}, \&$ Besar bin Ngah ${ }^{2}$ \\ ${ }^{1}$ Faculty of Islamic Sciences, Al-Madinah International University, Kuala Lumpur, Malaysia \\ ${ }^{2}$ Faculty of Finance and Administrative Sciences, Al-Madinah International University, Kuala Lumpur, Malaysia \\ Correspondence: Taman Desa Petaling, 57100 Kuala Lumpur, Malaysia. Tel: 6011-6050-3754. E-mail: \\ beyzekoub@yahoo.fr
}

Received: June 3, 2019 Accepted: June 17, $2019 \quad$ Online Published: June 30, 2019

doi:10.5539/ass.v15n7p134 URL: https://doi.org/10.5539/ass.v15n7p134

\begin{abstract}
This study tends to monitor the phases of fast food chains industry at MacDonald's in Kuala Lumpur at Malaysia and check its compliance with Sharia restrictions based on halāl food regulations in Sürah al-Mā'idah. Besides, this study eyes to make sure that the food is edible and safe from any kind of ingredient or component that might harm the consumer's health or have any negative impact on his religion. The deductive method has been used to conclude the most important sharia restrictions related to the acquisition of haläl food. In addition, a qualitative research method with a case study was used to monitor the operations of the fast food industry in McDonald's in Malaysia. Furthermore, a set of questions has been used for an interview with two senior staff members of McDonald's in order to gain a deep understanding of industry processes halāl food. These questions were developed based on halāl food regulations in Sürah al-Mā'idah. In this study, eight emergent themes have been discovered while doing analysis which are: Food Hygiene and Safety, Ingredient, Equipment and Environment, Packaging, Processing, Storage and Transportation, Staff and Sharia Advisor. The result of this study proved that Mcdonald's Fast-Food in Kuala Lumpur comply with the halāl food regulations stated in Sürah al-Mä'idah. This study might benefit the international and domestic food companies with a greater concern on Sharia requirements on food handling from production to marketing and from preparation to serving.
\end{abstract}

Keywords: Halāl, Mcdonald's Fast-Food, Sūrah Al-Mā'idah, Kuala Lumpur

\section{Introduction}

The companions of the prophet (May Allāh be pleased with them) used to seek halāl in every aspect of their life especially in their food, and the Qur'ān was very clear in determining and answering their query. According to Qur'ān, halāl is anything that benefits and does not bring harm to the human body, mind and religion. It was stated clearly in the Qur'ān that His servants are permitted to benefit from all what the earth contains and produces such as food, crops and produces with condition of being halāl, good and it is not harmful to the body or to the mind.

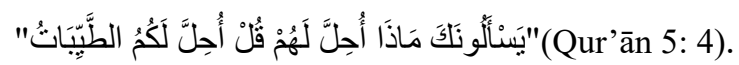

"They ask you what has been made lawful to them. Say: 'All clean things have been made lawful to you" (Ansari, 1989, Vol. 2, p. 135).

The Sunnah as well has confirmed the importance of seeking the halāl food since it is considered as requirement and prerequisite for the acceptance of righteous deeds. The Prophet (peace and blessings of Alläh be upon him) said:

"O people, God is good and does not accept anything but good" (Muslim, 2002, V 2, p. 703).

The commentators of the scholars differed in the scope of the description of the good mentioned in the aforementioned verses. However, on the authority of at- Tabarī: "At-Tayyib means what is pure, not unclean or forbidden" (At- Tabarī, 2001, V3, p. 301). Al-Māturīdī on the other hand defined Tayyib as "What pleases the soul when eaten, since the soul does not enjoy the eating from all haläl, however it is pleased with what is good and delicious" (Al- Māturīdī, 2005, V1, p. 618). Fakhr al-Ddīn al-Rrāzī described at- Tayyib as the one which is delicious and desired (Ar-Rrāzī, 1999, V11, p. 290). As for Muhammed Abdo his description of at- Tayyib as 
something which is corruptly acquired such as transgressing and taking the rights of others unjustly (Rida, 1990, V2, p. 71). It can be concluded after presenting the myriad opinions of scholars that: "The haläl and Tayyib is all what is pleased and desired unless it is harmful, it is disgusted, it is forbidden, it is an uncleaned, it is acquired from forbidden wealth, it involves the unjust taking of the right of others and non-moderation in consumption (overconsumption)". Based on the above discussion, it can be concluded that every food which is authorized by Sharia is lawful for people since food plays a vital role in human's life. Some scientists said: "All what it is permitted by Allāh is beneficial for the body and religion as well" (Ibn Kathīr, 1999, V31, p. 488). The benefit of haläl food to the body is by strengthening it to withstand hardness and make it more resilient to work. From a religious perspective, halāl food give a person more power to engage in all acts of worship. Therefore, the food in order to be halāl, has to be good. The noble Qur'ān has clearly provided enough evidences to all mankind to choose good and harmless sustenance in order to benefit their bodies and souls as well. Furthermore, it is consistent with what the Creator has commanded them. For Muslims they have now options to select and consume the best of foods based on sharia requirements and for the non-Muslims the consumption of haläl food is a good option for them. Additionally, it is very important to profess that the government of Malaysia plays a role in protecting Muslims consumers in Malaysia by implementing Islamic agencies and associations to monitor the process of halāl products as urged by sharia Islamic law.

\subsection{Problem Statement}

Assuring that the halāl requirement stated by verses in Sürah al-Mā'idah is required by all industries. At the same time, industries have to make sure the halāl status should be sustainable at every time in the organization. Therefore, some Muslims are cautious when it comes to consuming the manufactured or processed food by the foreign companies. As a consequence, they abstain from eating their food and be cautious of committing unlawful deeds. While, others do not bother themselves in eating in such foreign food chains restaurants and do not question whether the food served is halāl (permitted) or harām (prohibited). Such behaviour does contradict with the sharia rules and regulations in clarifying the rules of halāl and make the people in a state of solace in this practice and lifting all the doubts about it.

\subsection{Objectives}

This research aims primarily to shed light on the most crucial sharia regulations related to the acquisition of halāl food in order to raise awareness among Muslims regarding the provisions of foods that are permissible and forbidden in the light of contemporary developments. Furthermore, it allows the international and domestic food companies to have an idea about the sharia rules and regulations of food processing from production to marketing. Secondly, this research aims to monitor the phases of fast food chains industry in MacDonald's and check its compliance with sharia restrictions that were achieved by this study. Besides, this study eyes to make sure that the food is edible and safe from any kind of ingredient or component that might harm the consumer's health or have any negative impact on his religion as well.

\subsection{Delimitation of the Study}

The research has examined ten Madanī مدني verses from Sürah Al Mā'idah which are: (1), (2), (3), (4), (5), (87), (88), (90), (95) and (96).

This study is limited to participants from the district of Kuala Lumpur Malaysia, that is why the findings gained through this study might be different in other countries, and with other participants, in particular a non-Muslim countries and participants.

\subsection{Literature Review}

Many studies were conducted to emphasize the phenomenon of knowledge and halāl food among food industries and to experience the monitoring of haläl food in the manufactories of some countries. A research done by Rahman Ahmed and Mohd Yosoff Mohamad in 2011 explored some sorts of traditional haläl food and analyzed the knowledge of entrepreneurs about it. A questionnaire was constructed to gather information on the issue. The sample of the study were 300 entrepreneurs from the state of Terengganu and Kelantan and they were selected through the non-probability sampling techniques. The research findings found 10 kinds of foods that has been identified as traditional foods such as fish cracker, traditional Malay dessert, ketchup, fish sauce, chilli sauce, canned food, mee hoon, Malay traditional noodles, rice, and flying bread. Another finding shows that rice dishes was the most familiar type of food industries among the 10 types. Moreover, the majority of the respondents have a good knowledge on halāl food concept in Islam (Ahmed \& Mohamad, 2011, p. 216). Similarly, in the same country Malaysia, Muhammad Haziq Hassan, Sazelin Arif and Safiah Sidek conducted a research in 2015 about knowledge and practice for implementing internal halāl assurance system among haläl executives. The 
qualitative research approach was used in this study by using an interview, the participants were 39 executives at the halāl food premises throughout the state of Malacca. It was found that the halāl executives implemented the IHAS mainly based on their knowledge about Islam as they lack knowledge on the requirements of IHAS. Therefore, it was proposed that they should be given continuous training so that a sustainable implementation of IHAS at the food premises can be achieved (Hassan et al., 2015, p. 57). In contrast, Bahron (2016) examined the influence of dietary halāl practices on organizational performance among the halāl food industry in Malaysia. The study used quantitative research method, 241 questionnaires were distributed to the halāl food industry in Malaysia and they were usable for analysis at an organizational level. The respondents of this study were internal committee members who are specially appointed for haläl dietary management control within the organization. The findings showed that the level of halāl practices and the performance of the halāl food industry in Malaysia is positive (Bahron, 2016, p. 28909). One study done in Indonesia by Lopez in 2017 discussed the integration of the standards of halāl products in Muslim countries and implementing the Islamic way of undergoing contracts and transactions (Lopez, 2017, p. 242). Although the importance of all these researches in the Muslim daily life, this study differs from the others in terms of focusing on the regulations of halāl food from Surah al-Má'idah, and extracting and analyzing the regulations of haläl food in this Surah, the next step is to apply what have been extracted on the fast food McDonald's companies at Malaysia in order to monitor the operations of making food and deliver it.

\subsection{Methods}

The deductive method has been used to conclude the most important sharia restrictions related to the acquisition of haläl food in order to encourage its practice and detection of any suspicious product that does not comply with its norms, and then the qualitative research method is employed in this study, because it is the best approach that provide deep understanding of how sharia requirements is entirely practiced on fast food restaurants processing. The case study designed was used in this study to answer this general question: How McDonald's process its food from production to marketing and from preparation to serving?

This case study was employed to monitor the operations of the fast food industry in McDonald's in Malaysia in order to gain a deep understanding of industry processes halāl food in this study.

The participants of this study were one female and one male, the data collection of this study was conducted within two days, where the researcher met the respondents in the McDonald's of Kuala Lumpur for 20 minutes, and before starting the interview, the researcher explained about the study objectives. The interview questions for this study contained nine questions (see sample of the interview questions).

Q1. Is the food served at McDonald's Hygienic and Safe? If yes, can you tell me if the served food complied with Islamic Law?

Q2. Do you ensure that all the raw materials are haläl?

Q3. Are all equipments used in preparations of food at McDonald's free from prohibited components and free from toxicity? If yes, do you ensure that all sections of the restaurant are clean and tidy at all time?

Q4. Do you ensure that the packaging of all food items and ingredients are clean from any venomous which can effect on the haläl food?

Q5. Do you ensure that all food processing done in a correct and complied with sharia Islamic law?

Q6. Is the storage of food materials not mixed with non- halāl materials? If yes, do you ensure that transportation process is free from impurities and not mixed up with non- halāl materials?

Q7. Do all staff of McDonald's have attend the relevant courses on halāl food Management on a regular basis? If yes, do the non-Muslims Staff at McDonald's observe the halāl procedures During their duty hours? And do the management team keep in check the working place and the employees?

Q8. Do you have sharia Advisor? If yes, how many of them and who appointed them and trained them? And what is the role of sharia Advisor at the McDonald's?

Q9. Is the restaurant recognized as halāl by government of Malaysia?

This interview was conducted by the lead author, and it was transcribed as a first step in the analysis procedure by using a digital voice recorder, a thematic analysis has been applied for the data analysis.

\section{Definition of halāl}

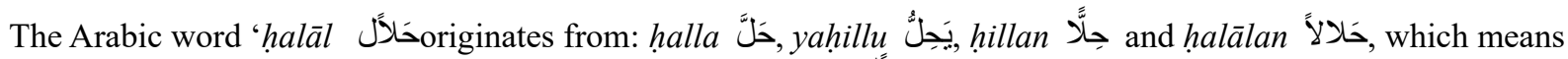

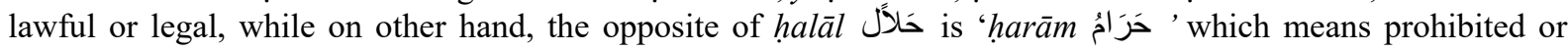


forbidden.

The noble Qur'ān has been used the term "haläl" as a verb and as a noun in fifty-one verses, including twelve verses which are Makkī مكّي and thirty-nine verses which are Madanī مدني (Abdel Baqi, 1945, pp. 215-216).

Therefore, the halāl concept as per our scholars is simply means: "what is authorized by the religion to perform it" (Al- Qaradawi, 2012, p. 16). Hence, we mean by haläl food the food which is: "prepared by following Islamic dietary laws and regulations which determine what is permissible, lawful and clean" (Halal Food Standards, 2019).

\section{Evidences of Ḥalāl Food Regulations from Sūrat Al-Mā'idah}

The legitimate Qur'ānic verses that are discussed in this research concerning halāl food and drinks are as listed hereunder;

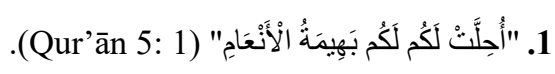

“All grazing beasts of the flock are permitted to you" (Ansari, 1989, Vol. 2, p. 127).

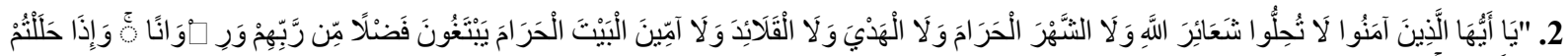

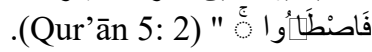

"Believers! Neither desecrate the symbols of (devotion to) Allah, nor the holy month, nor the animals of offering, nor the animals wearing collars indicating they are for sacrifice, nor ill-treat those who have set out for the Holy House seeking from their Lord His bounty and good pleasure. But once you are free from Pilgrimage obligations, you are free to hunt" (Ansari, 1989, Vol. 2, pp. 128-130).

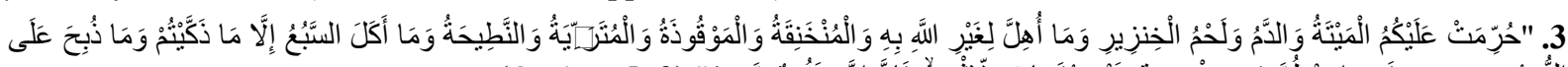

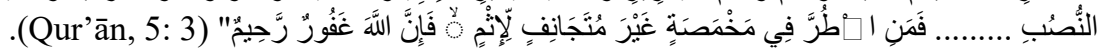

"Forbidden to you are carrion, blood, the flesh of swine, the animal slaughtered in any name other than Allāh's, the animal which has either been strangled, killed by blows, has died of a fall, by goring or that devoured by a beast of prey - unless it be that which you yourselves might have slaughtered while it was still alive and that which was slaughtered at the altars..... As for he who is driven by hunger, without being wilfully inclined to sin, surely Allah is All-Forgiving, All-Compassionate" (Ansari, 1989, Vol. 2, pp. 130-134).

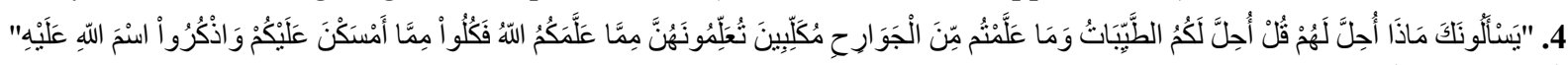

.(Qur'ān 5: 4)

"They ask you what has been made lawful to them. Say: 'All clean things have been made lawful to you, and such hunting animals as you teach, training them to hunt, teaching them the knowledge Allah has given you - you may eat what they catch for you - but invoke the name of Allah on it" (Ansari, 1989, Vol. 3, p. 135).

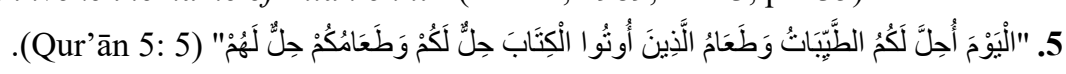

"This day all good things have been made lawful to you. The food of the People of the Book is permitted to you, and your food is permitted to them" (Ansari, 1989, Vol. 2, p. 137).

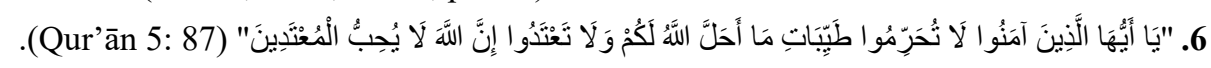

"Believers! Do not hold as unlawful the good things which Allah has made lawful to you and do not exceed the bounds of right.5 Allah does not love those who transgress the bounds of right" (Ansari, 1989, Vol. 2, p. 188).

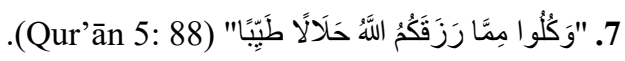

"And partake of the lawful, good things which Allah has provided you as sustenance" (Ansari, 1989, Vol. 2, p. $188)$.

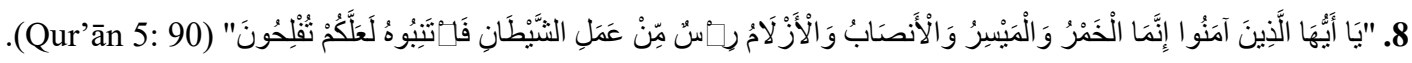

"Believers! Intoxicants, games of chance, idolatrous sacrifices at altars, and divining arrows are all abominations, the handiwork of Satan. So turn wholly away from it that you may attain to true success" (Ansari, 1989, Vol. 2, p. 191).

9. 9.

"Believers! Do not kill game while you are in the state of pilgrim sanctity" (Ansari, 1989, Vol. 2, p. 193).

10.

"The game of the water and eating thereof are permitted to you as a provision for you (who are settled) and for those on a journey" (Ansari, 1989, Vol. 2, p. 195). 


\subsection{Findings of Haläl Food Regulations in Sürah Al-Mä idah}

The main findings of the above evidences of halāl food regulations from sūrah al-Mā'idah are as follows:

1. Permitted to consume all aquatic animals whether they are caught or found dead, unless they are hazardous to life or health.

2. Permitted to eat all land animals -if they are not hazardous to life or health- except:

- Animals that are not slaughtered according to Islam, or dead before slaughtering.

- Swine/pork and its by-products.

- Mules and domestic donkeys.

- Any Scavenger or contaminated animals (Jallālah) until it is purified from impurity.

- All animals that not allowed to be killed in Islamic law such as ants, bees, frogs and woodpecker birds.

- All animals that permitted to be killed in Islamic law such as rat, geckos, crow, snake and the rabid dog.

- All carnivorous animals with claws or fangs such as lions, tigers, bears.

- All birds of prey with claws such as eagles, vultures, owls.

- All animals which have been killed in other name than Allāh.

3. Forbidding to eat every harmful food even if it is haläl, and it is not allowed to consume the lawful food which is mixed up with the unlawful food, also it is not permissible to waste food.

4. Forbidding to consume any food containing toxic except if the toxin can be removed during processing.

5. Permitted to consume all drinks except: the blood and its derivatives, Alcoholic drinks and its derivatives, and all forms of toxin and contaminated drinks.

6. Permitted the consumption of forbidden foods and drinks according to the points above in conditions of fear of harm or loss of the soul or loss of some parts of the body when quitting the consumption.

7. The main regulations of haläl food in Sürah Al-Mä'idah are:

- The Impermissibility of forbidding the lawful foods and permitting the unlawful foods.

- All Tayyib (good) foods are lawful.

- All what is permissible to eat from a land animals must be slaughtered according to Islamic Law.

- The sacrifices of Jews and Christians are lawful for Muslims if they are slaughtered according to their respective Scriptures.

- Permitted all aquatic animals to be used for food whether they are caught or found Dead, and it does not matter who caught them.

- All malicious foods are unlawful.

- All the dead land animals are unlawful except the dead locusts.

- All what is forbidden to eat from a land animals is not allowed even if they are slaughtered according to Islamic Law.

- The Impermissibility of drinking the impure liquids.

- Permitting the forbidden foods and drinks in conditions of necessity.

\section{Findings of Empirical Analysis of Medonald's Fast-Food in Malaysia}

The findings of this part of study were developed through the thematic analysis, eight emergent themes of halāl food requirement practices have been identified as performance predictors in this part of our study which are: Food Hygiene and Safety, Ingredient, Equipment and environment, Packaging, Processing, Storage and Transportation, Staff and Sharia Adviser. The themes were then discussed by including verbatim quotations from MacDonald's interview in Kuala Lumpur, Malaysia without mentioning participant's names.

Theme 1. Food Hygiene and Safety

It is mentioned in the dictionary that the word 'hygiene' means: "Conditions or practices conducive to maintaining health and preventing disease, especially through cleanliness" (Oxford, 2003, p. 852).

Therefore, the term of food hygiene means: "the conditions and measures necessary to ensure the safety of food from production to consumption. Food can become contaminated at any point during slaughtering or harvesting, 
processing, storage, distribution, transportation and preparation. Lack of adequate food hygiene can lead to foodborne diseases and death of the consumer" (Foodsafety, 2019).

In order to ensure the safety of foods in shops, stores and restaurants, government of Malaysia have implemented in 2009 a new set of regulations about the food hygiene and safety, and the violation of the regulations implemented by the law may lead to the suspension of certificates and closure of premises, and the general objective of the food hygiene regulations 2009 according to ministry of health Malaysia is to "provide an infrastructure to control the hygiene and safety of food sold in the country to protect public health" (Chandran, 2009 , p. 6). As the participant mentioned in the interview that:

"For us to get haläl certificate from JAKIM there are a few requirements we have to follow which are: to ensure that all products are halāl, follow all other government requirements and regulation, must be Muslims working in the kitchen in one time 24hrs, cleaning is compulsory and daily, compulsory to have SOP to ensure to food hygiene and safety".

From the participant interview, we observed that all halāl food comply with Islamic Law, all items served are certified as halāl and the food consumed is hygienic and safe.

Theme 2. Ingredient

It is stated that the word 'ingredient' means: "Any of the foods or substances that are combined to make a particular dish" (Oxford, 2003, p. 890).

According to the previous guidelines of halāl food gathered from Sūrah al-Mā'idah, Muslim followers cannot consume a numbers of products listed as forbidden by Islamic law.

Therefore, ingredients in food like food colouring, preservatives, antioxidants, thickeners, salt and flavour enhancers and other additives must all coming from the right source as listed above, and the Muslim should be aware about the haläl ingredient in food and products. As the participant mentioned in the interview that:

"All ingredients intended to be used in the restaurant must be halāl certified by JAKIM, we only buy products from supplier who have halāl certificate, JAKIM has 67 overseas halāl authorities which we can buy from them, and locally only buy from JAKIM certificate supliers". Also said that: "We ensure that all the raw materials are halāl, restaurants is following all halāl compliance, engage with all related halāl authorities and any other related Muslim association".

From the participant interview, we concluded that all imported ingredients are certified halāl by the source country local and the food or its ingredients do not contain any parts or products of animals that are non- haläl according to Islamic law.

\section{Theme 3. Equipment and Environment}

The equipment means: "The process of supplying someone or something with necessary equipment" (Oxford, 2003 , p. 587), while the 'environment' means: "The surroundings or conditions in which a person, animal, or plant lives or operates" (Oxford, 2003, p. 581).

Department of Standards Malaysia has underlined that: "The devices, utensils, machines and processing aids used for processing haläl food shall be designed and constructed to facilitate cleaning and shall not be made of or contain any materials that are decreed as najis by Shariah law and shall be used only for halāl food" (Standards Malaysia, 2009, p. 4). In addition, it is states that: "The environment shall be clean and its cleaning schedule shall be properly regulated and free from pollution, and the cleaning schedule shall be prepared and properly monitored" (Malaysia Halal Certification, 2015, p. 21). As the participant mentioned in the interview that:

"All equipment used in preparations of food had been certified Clean \& Haläl, which means are free from Prohibited components, and free from toxicity", "All sections of the restaurant are clean and tidy at all time, for example we have policy and procedure how to do cleanliness like toilet every $30 \mathrm{~min}$ if not in busy time, otherwise every 15 min".

Subsequently, the interview concludes that all materials used in preparations of food are haläl, clean and safe for use and not made from harmful materials and the working environment is clean and tidy at all times.

Theme 4. Packaging

The word packaging means: "Materials used to wrap or protect goods" (Oxford, 2003, p. 1262).

Therefore, the packaging materials of halāl food must fulfill the following requirements: 
- "The packaging materials shall not be made from any raw materials that are decreed as najis by sharia law;

- It is not prepared, processed or manufactured using equipment that is contaminated with things that are najis as decreed by sharia law;

- During its preparation, processing, storage or transportation, it shall be physically separated from any other food that does not meet the requirements stated in item, or any other things that have been decreed as najis by sharia law;

- The packaging material does not have any toxic effect on the halāl food;

- Packaging design, sign, symbol, logo, name and picture shall not be misleading and/or contravening the principles of sharia law;

- Packing process shall be carried out in a clean and hygienic manner and in sound sanitary conditions;

- Labelling material used in direct contact with the product shall be non-hazardous; and

- Advertising shall not contravene with the principles of sharia law and shall not display indecent elements which are against sharia law" (Standard Malaysia, 2009, p. 10)

In addition, according to Manual Procedure for Malaysia Halal Certification, the packaging label must consist of information among which are: "Name of product, Malaysia haläl Logo, List of ingredients, Coding number to show the date and/ or production batch number, expiry date and country of origin" (Malaysia Halal Certification, 2015, p. 18)

As the participant mentioned in the interview that:

"We ensure that the Packaging of all food items and ingredients does not have any bad impact on the halāl food".

Therefore, we observed that the industry ensures that the packaging of all food are halāl, clean and safe and not mixed with non- halāl materials at all stages of packaging processes.

\section{Theme 5. Processing}

The English word 'processing' means: "A series of actions or steps taken in order to achieve a particular end" (Oxford, 2003, p. 1403).

According to Department of Standards Malaysia, all processed halāl food shall meet the following requirements:

1- "Food or its ingredients shall not be processed using any components or products of animals that are nonhalāl by Shariah law or of halāl food any components or products of animals that are not slaughtered according to Shariah law;

2- Food shall not be processed using anything in any quantity that is decreed as najis by Shariah law;

3- Processed food or its ingredients shall be safe for consumption, non-poisonous, non-intoxicating or non-hazardous to health;

4- Food shall be prepared, processed or manufactured using equipment and facilities that are free from contamination with najis" (Standards Malaysia, 2009, p. 7). As the participant mentioned in the interview that:

"We ensure that the food processing is done in a correct way which does not lead to contradiction with Sharia Islamic law"

In addition, in Malaysia's haläl certification: "tool and elements of worship are not allowed in the processing area, starting from the reception area for raw materials until the finished products, storage area and serving place. Failure to do could lead to the revocation of halāl certificate and can lead to action by the authority in the certification of halāl" (Malaysia Halal Certification, 2015, pp. 22, 48-55). As the participant mentioned in the interview that:

"We do not allow the Muslim staff to pray in the processing area in order do not upset the non-Muslim staff or maybe they will ask for doing their prayers".

Therefore, after interviewing the industry, we observed that the food processing is not in contact, mixed or adjacent to any foods that contain any unclean elements according to Islamic law and fatwa, and also prayers are not allowed in the processing area.

Theme 6. Storage and Transportation

The English word 'Storage' means: "The action or method of storing something for future use." (Oxford, 2003, p. 
1743), and the transportation is "The action of transporting someone or something or the process of being transported" (Oxford, 2003, p. 1876). According to Department of Standards Malaysia, Storage and Transportation must fulfill the following requirements:

1- "All halāl food that are stored, transported, displayed, sold and/or served shall be categorized and labelled halāl and segregated at every stage so as to prevent them from being mixed or contaminated with things that are non-ḥalāl.

2- Products based on najasa al-Mughalazah shall be stored in dedicated place.

3- Transportation vehicles such as bonded truck shall be dedicated and appropriate to the type of the halāl food and satisfy hygiene and sanitation condition" (Standards Malaysia, 2009, p. 10). As the participant mentioned in the interview that:

"The storage of food materials is not mixed with Non-halāl materials". Also: "we have distribution, and the transportation has halāl certificate”.

Therefore, we observed that the storage of halāl products is not in contact, mixed or adjacent to any foods that contain any unclean elements according to Islamic law and fatwa and the transportation used is physically clean and free from impurities, and is used for haläl products only in order to make sure that the products are in good condition and safe to use.

Theme 7. Staff

The word 'Staff' means: "All the people employed by a particular organization" (Oxford, 2003, p. 1719). According to Manual Procedure for Malaysia Halal Certification:

1- "The Companies shall appoint one Malaysian Muslim supervisor and shall appoint a Malaysian Muslim workers with a certain number according to the size or category of the companies and their role;

2- Employees are evaluated in terms of training requirements such as halāl training courses, food handlers, practice code of ethics and Good Hygienic Practices;

3- The management shall ensure that all workers attended Malaysia haläl certification training, and that all workers shall practice code of ethics and Good Hygienic Practices, and also workers shall wear proper and suitable attire;

4- The management team shall provide basic amenities and ensure the worker's Welfare is taken care of, including: Suitable praying area for Muslim workers, permission to perform daily fardhu and Friday prayers, changing room and Pantry; and

5- The management shall appoint Muslim halāl executive officers or establish a committee which consist of Muslim personnel who are responsible to ensure the effectiveness in implementation of internal halāl control system" (Malaysia Halal Certification, 2015, pp. 20-22). As the participant mentioned in the interview that:

"We have halāl awareness training classes for all staff between 10-15 min on what is halāl. We have to do a quarter training for all staff because we always have new people coming. Staff are not allowed to bring outside food because in order to avoid the halāl cross contamination to happen. We provide meals for all staff. Fridays Prayers are compulsory for all males staff otherwise they will be punished. Smoking not allowed. The nonMuslim Staff at Mcdonald's observed the halal procedures during their duty hours". The participant mentioned also that:

"We have been chosen best employer in Malaysia last three years".

In addition, the team manager must keep 'scope creep' in check. As the participant mentioned in the interview that:

"The senior manager shall ensure that all the raw materials are halāl, restaurants is following all halāl compliance, engage with all related halāl authorities and any other related Muslim association, in addition: "The chief manager must check to products if not expired, and whether the crew follow the cleanliness and doing the cooking"

Therefore, we observed that the industry ensures that all staffs attended courses related to haläl food handling, the Non-Muslims Staff at the industry observed the halāl procedures during their duty hours, the staff are not sick during their duty hours and the management team shall keep in check and control the working place and the employees. 


\section{Theme 8. Sharia Adviser}

The word 'Sharia' or 'sharia law' is: "the Islamic legal system derived from the religious precepts of Islam, particularly the Quran and the Hadith (Sunnah), the shari'ah is a complete way of life; no aspect of human life is outside its domain. Islam expects a Muslim to follow its laws in every aspect of life: personal and familial, religious and social, moral and political, economic and business, etc" (IslamiCity, 2019), while the word 'Adviser' means: "A person who gives advice in a particular field" (Oxford, 2003, p. 24). It is stated that: "the auditing shall be carried out by minimum of two officers, who are competent in Islamic education and technical matters" (Malaysia Halal Certification, 2015, pp. 46). As the participant mentioned in the interview that:

"Two Shariah expert from outside have been appointed by Mcdonald's as shariah advisers who are available at any time to oversee and advice on halal matters, but till now we did not face any issue regarding sharia, also the sharia advisor used to conduct talks on haläl training program designed to help our workers to build their trust at work and to gain an advanced level of understanding of the Islamic haläl food". In addition: "We have to undergo relevant courses conducted by JAKIM on halāl matters, halal assurance systems and halal auditing workshop etc. We are supposed to attend McD IHC (Investment Holding Company) meetings, give our opinion and advice on any arising issues related to halāl matters".

Therefore, we observed that the industry makes sure appoint two external Islamic expert to be trained by JAKIM in order to give their opinions and advices on any arising issues related to haläl matters, also we observed that the Sharia Advisers conduct haläl training program for all workers.

\section{Conclusion}

In a nutshell, this study was about to acknowledge the Mcdonald's fast- food in Malaysia based on haläl food regulations in Sürah al-Mä'idah. Eight themes emerged from the interview transcription based on the research questions. The findings of this study showed that the MacDonald's fast food in Malaysia complied with the regulations and restriction of sharia Islamic Law stated in Surah Al-Maidah. Thus the level of MacDonald's fast food performance from production to marketing and from preparation to serving in Malaysia is positive and fully complied with halāl requirements. Hence, additional research is needed from time to time to ensure that the sharia requirements is entirely practiced on fast food restaurants processing and handling.

\section{Acknowledgements}

The authors would like to thank the Research Management Centre (RMC), Al-Madinah International University, Kuala Lumpur, Malaysia, for funding the research under the research grant.

\section{References}

Abdel Baqi, M. (1945), Al Mu'jam Al Mufahras Li Alfazh Al Quran Al Karim (pp. 215-216). Egypt: Dar al-Kitab al-Masriya.

Abul A'la Maududi. (1989). Towards Understanding the Quran, translaed by: Zafar Ishaq Ansari (Vol. 2, pp. 127-195), London: The Islmaic Foundation.

Al- Māturīdì, A. (2005). Ta'wrīlāt Ahl Al-Sunnah (V1, p. 618). Beirūt: Darul Kutub Al-'ilmiyyah.

Al- Qaradawi, Y. (2012). Haläl and Harām in Islam (p. 16). Cairo: Wahba Library.

Al- Qur'ān. Chapter Al-Ma'idah. Verses: (1), (2), (3), (4), (5), (87), (88), (90), (95) and (96).

Al-Rrāzī, F. (1999). Mafātīh al ghayb, (V11, p. 290), Beirūt: DÉr al- Ihya' a- Turāth al- 'Arabī.

Amani Burhanuddin Lopez. (2017). Shariah Conditions and Regulations for Halal Food: Indonesia Experience (Vol. 17, No. 1, p. 242). Indenesia: Ahkam Journal Ilmu Sharia.

At- Ṭabarī, M. (2001). Jāmi' Al-Bayān fì Ta'wāl Al-Qur'ān (V3, p. 301). Egypt: Dār Al-Hajar.

Food Service. (2019). Halal Food Standards, Canada: University of Toronto. Retrieved from https://ueat.utoronto.ca/everythingfood/food-standards/halal-food-standards/

Hassan, M. H., Arif, S., \& Sidek, S. (2015). Knowledge and Practice for Implementing Internal Halal Assurance System among Halal Executives. Asian Social Science, 11(17), 57. https://doi.org/10.5539/ass.v11n17p57

Ibn Kathīr, A. (1999). Tafsìr al-Qur'ān al-Ažìm (V31, p. 488). Taiba House for Publishing and Distribution.

Islami City. (2019). Islamic Law. Retrieved from https://www.islamicity.org/topics/islamic-law-sharia/

JAKIM. (2015). Manual Procedure for Malaysia Halāl Certification (3rd ed., pp. 10-11, 18-22, 48-55). Malaysia: Firdaus Press. 
Malaysia Standard. (2009). Halāl Food-Production, Preparation, Handling, and Storage- General Guidelines, (2nd ed., p. 4, 7, 10). Department of Standard Malaysia.

Muslim, H. (2002). Saḥịh Muslim (V 2, p. 703). DÉr al- Ihya' a- Turath al- 'Arabi.

Othman, B., Shaarani, S. Md., \& Bahron, A. (2016). An Empirical Analysis of Halal Practices on Organizational Performance among Food Industries. International Journal of Current Research, 8(3), 28909.

Oxford Dictionnary of English. (2003). (2nd ed., pp. 24, 581, 587, 852, 890, 1262, 1403, 1624, 1719, 1743 , 1876). United Kingdom: Oxford University Press.

Rahman, A. H. A., Ahmad, W. I. W., \& Mohd Yusoff Mohamad, Z. I. (2011). Knowledge on Halal Food amongst Food Industry Entrepreneurs in Malaysia. Asian Social Science, 7(12), 216. https://doi.org/10.5539/ass.v7n12p216

Rashid Reḍa, M. (1990). Tafsìr al-Qur'ān al-hakìm (V2, p. 71). Egypt: Egyptian General Book Organization.

Thangayah, C. (2009). Food Hygiene Regulations (p. 6). Ministry of Health Malaysia.

World health organization. (2019). the Five Keys to Safer Food Programme. Retrieved from https://www.who.int/foodsafety/areas_work/food-hygiene/5keys/en/

\section{Copyrights}

Copyright for this article is retained by the author(s), with first publication rights granted to the journal.

This is an open-access article distributed under the terms and conditions of the Creative Commons Attribution license (http://creativecommons.org/licenses/by/4.0/). 